\title{
Students' Problems in Pronouncing Non-Existing English Diphthongs in Indonesian Language
}

\author{
Yasinta Anwar*, Pasca Kalisa \\ Universitas Negeri Semarang, Indonesia \\ *Email: yasintaanwar6@gmail.com
}

DOI https://doi.org/10.15294/lc.v15i1.26261

Submitted 18 September 2020. Revised 30 September 2020. Accepted 18 October 2020

\begin{abstract}
One of the difficulties in learning the English language faced by Indonesian students is how to pronounce English sounds correctly. For several Indonesian students, producing English diphthong sounds could be difficult especially English diphthong sounds which do not exist in Indonesian ([Іә], [Uә], [ег], [еә] and [ou]). This study investigated the Indonesian students' problems English diphthong pronunciation. The objective of this study was to describe how well the English diphthong sounds are pronounced by the students and to find out the kind of errors that were mostly found in the pronunciation of students. The participants of this study were 35 students of the eleventh grade of SMK N 2 Salatiga. The instruments were the production test containing English diphthong sounds and interviews as additional data. In determining the achievement, the level of criterion by Tinambunan's criterion was used. Based on the data analysis, the total average of the incorrect numbers of English diphthong sounds in pronunciation made by students was $69 \%$ which was categorized as fair. In addition to it, the kinds of errors mostly found in the students' pronunciation English diphthong sounds were omission errors. According to the result of the interview, the causes of the errors were unfamiliarity of knowing English diphthong sounds, so the sounds of English appeared to pronounce with the closest Indonesian sounds.
\end{abstract}

Keywords: English diphthongs; Indonesian language; pronunciation problems

\section{INTRODUCTION}

English has been a significant language as several countries have adopted English across the world as a second language. In addition, English is one of all international languages, which is really important, not only as a feature of verbal communication but also as a feature of written communication.

One of the difficulties in learning the English language faced by Indonesian students is how to pronounce English sounds correctly. Syafei $(1988$, p. 1) states that pronunciation is very crucial because if non-native speakers have a terrible pronunciation, no regard how well his or her knowledge of English grammar and vocabulary, they will not be able to communicate verbally.

Generally, a lot of English learners as a foreign language face difficulty in pronunciation. The difficulty incudes the pronunciation of some unfamiliar sounds. For several learners, producing English diphthong sounds is difficult. The culture and behavior in their first language may cause them. Ramelan (1997, p. 9) states that the degree of similarity between the two languages also determines to learn difficulties. The more re- semblance between them, the more efficiently the language can be understood by the students.

As Roach (2009) states that a diphthong is indeed a move or glide through one vowel to another. The diphthong is the English vocal system that will be extended to further types of vowels, which cause the difficulties faced by EFL learners when trying to get efficient acquaintance. That is why several Indonesian students find it difficult to understand certain English sounds since they do not recognize the English sound features in their language and because they have not been taught to produce certain English sounds.

Some previous studies have been conducted dealing with the pronunciation of English diphthong sounds. However, they focus on how the students produce or pronounce the English sound and try to analyze the errors made by the students. Therefore, this research is different from the other researchers that have been mentioned above because this present research only focuses on the student production of the sound made by the students but also identify what kinds of errors are mostly found in students' pronunciation.

This research investigates how well the students produce the English diphthong sounds 
which Indonesian language or Bahasa does not have through a pronunciation test. The pronunciation test is used to analyze the students' problems in pronouncing the English diphthong sounds which do not exist in Indonesian. Besides, this research also finds out what kind of errors are mostly found in students' pronunciation when distinguishing the English diphthong sounds which do not exist in Indonesian.

Many Indonesian students find it difficult to learn English as a second language. In learning speaking, many students get problems when they practice to mastering their speaking skill. One of the problems is inappropriate pronunciation, especially the difficulties in pronouncing English vowels, consonants, and diphthongs that do not exist in Bahasa Indonesia. Al Zayed (2017) argues that, "the more differences in sounds between the two languages, the more errors of interferences will occur" (p. 86). Besides, Ahmed (2017) also argues that most students were unable to pronounce some sounds that are not available in their mother tongue. That is why the learners make errors in pronouncing unfamiliar sounds of their native language.

Language is a matter of habit, especially in pronunciation. The ability to hear and identify the sound system of English is another problem in producing foreign sounds by organ speech. Kosasih (2017) stated, that Indonesian students as non-native speakers facing difficulty in pronouncing the non-existing diphthongs and consonants sounds, students have to learn continuously in a certain period to mastering their English pronunciation. The non-existent sounds cause different patterns that can vary between syllables, Khan, Shehzad, \& Ullah (2017) mentioned that "this liberty plays significant grammatical function and is practiced to give a different meaning to similar words" (p. 20).

As stated by Gilakjani (2011) that pronunciation as an ability to communicate. Moedjito (2016) also argued that for effective oral communication, pronunciation is important. The speaker is intended to speak clearly and properly to be understandable. Without taking into consideration pronunciation, the speakers and listeners will have different interpretations. The production of sounds that are used by the speaker to make meaning is called pronunciation. Each English word has a different sound system, which causes difficulties in pronouncing the English word for most Indonesian students.

Pronunciation has become a serious problem when learning English. Many Indonesian students still faced pronunciation problems with
English vowel sounds. These difficulties may be caused by the difference between the sound system in Indonesian and English. Moedjito (2016) stated that segmental features are the most significant majority of pronunciation problems identified by the students. While, Ramelan (2003, p. 22) explained that there are two types of features, segmental and suprasegmental features. The priority in pronunciation for EFL learners is segmental features. Consonants and vowels belong to segmental features. It means that vowel sounds are one of the causes which are caused many Indonesian students faced the pronunciation problems.

Diphthongs are forms of vowels, in which a constant gliding motion connects two vowel sounds. Jones (1956, p. 22) stated that the sound is called a diphthong when produced by gliding through one letter to the next. Also, Jones (1956, p. 24) mentioned that English has nine diphthongs in all; these nine diphthongs can be categorized as closing and centering diphthongs. In closing diphthong, there are five diphthongs ([er], [ou], [ar], [av], and $[\square \mathrm{r}]$ ). There are four diphthongs in centering diphthongs ([Іә], [טə], [عə], and $[\square$ ə]). Besides, Roach $(2009$, p. 19) stated that the most important thing to remember about all the diphthongs is that the first part is considerably longer and stronger than the second part.

In the learning process, there will be an error and a mistake made by students. People often confused about the difference between those two words. Brown (2000, p. 217) states, "differentiate errors and mistakes is necessary, two concepts which are technically very different." Ellis (1997, p. 17) in her books entitled 'Second Language Acquisition' also explains, "we need to distinguish errors and mistakes. Errors reflect gaps in the knowledge of the learner. These occur because the learner does not know what is correct. Mistake reflects occasional performance lapses that occur because the learner is unable to perform what he or she knows in a particular instance." Besides, Jing, Xiaodong, and Yu (2016) also stated that an error is a structural digression of students who are unfamiliar with the target language rules. While a mistake is related to insufficient performance concern, carelessness, or another aspect of performance.

According to Brown (2000, p. 223-227), several sources may influence errors in second language learning, they are: Interlingual Transfer. An interlingual transfer is often called as interference or transmission of language. Brown (2000, p. 224) stated that a good deal interlingual transfers from the native language describe the begin- 
ning phases of learning a second language. In other words, the first language causes interlingual errors. One of the common problems in foreign language teaching is language interference. Ellis (1997, p. 51) also assumed that interference could be identified as a foreign language error used by learners whose mother tongue can be traced. Intralingual Transfer. An intralingual transfer is an essential element in the foreign language. Brown (2000, p. 224) stated that the predomination of interference defines early stages of language learning. But after the learners have started to gain aspects throughout the current method, there is an increasingly intralingual universal communication in the target language.

The Context of Learning. According to Brown (2000, p. 226), he stated that the context of learning relates to the social environment. When it comes to school learning, the learning context refers to the teachers and the content in the classroom. In the case of school learning or classroom context, teachers and materials are very influential. Strategies. According to Brown (2000, p. 227), he stated that communication strategy is a conscious use of a verbal or nonverbal system for efficient information communication. The lack of knowledge causes much trouble when learners want to communicate using a foreign language. Therefore, they use various forms of communication strategy to solve these problems.

There are three types of pronunciation error, they are: Substitution. Crystal (1985, p. 295) stated that a type of error which are defined by the replacement of an item is called a substitution. While Fromkin (in Juniarti 2019) also adds that substitutions happened when a disturber replaced one element. The example of substitution is when a word 'tears' / troz/ is pronounced /tierz/ or /tcarz/. Insertion is also called addition, is a type of error defined by the existence of an element that should not be existing in wellformed utterances normally (Fauziati as cited in Juniartuni, 2019). The example of insertion is when the word 'tourist' / turrist/ is pronounced [turaist]. Another example is when the word 'cared' /keəd/ pronounced as /kerrəd/.

Omission. Fauziati (in Juniartuni 2019) explained that the absence of an element that has to exist in the formed utterances is characteristic of omission or deletion. For example, in the word 'late' /1rt/, while it is should be pronounced as / leit/.

According to Ellis (1997, p. 15-20), there are ways to analyze the data. They are: Identifying Errors. In this section, the researcher lists the correct phonetic transcripts of the words that are tested in the speaking test. Then, the researcher listens to the recording of the students carefully and compare their pronunciation to the correct phonetic transcription. Describing Errors. In the next step, the researcher makes the phonetic transcription based on the students' recording and correct the errors. Then, the researcher classifies the types of errors including omission and insertion. Explaining Errors. After the errors are identified and described, the researcher explains why the errors occur and calculates the errors the students made in relation to English diphthong pronunciation and present them in the form of a percentage.

Evaluation. The last step is the researcher concludes the analysis of the errors in the speaking test. This study focuses on the students' problems in pronouncing the vowel sounds of English [eı], [चә], [ег], [еә[, and [әш] which do not exist in Bahasa Indonesia. The researcher uses speaking test to find out how well the diphthong sounds of English [eI], [चә], [eI], [eә[, and [әv] are pronounced by the students. The students are asked to read aloud some words, and then their voice is recorded. After getting the data from the speaking test, the researcher analyzes the types of errors that may occur in pronouncing English diphthong sound [eI], [चә], [er], [eə], and [əv]. The researcher uses an interview as additional data to know what kind of errors are mostly found in the students' speaking test. The interview contains some questions related to the pronunciation problems experienced. After getting the result, the researcher writes down the conclusions and suggestions based on the findings.

\section{METHODS}

The researcher chooses a descriptive qualitative method in this research depending on the process and purposes. Qualitative research is used to answer how well the participants pronounce the vowel sounds of English which do not exist in Bahasa Indonesia through data collection, data analysis, and the conclusion depending on data analysis (Nassaji, 2015).

According to Arikunto (2010: 173), "Population is a set of all elements possessing one or more attributes of interest." The researcher chooses the participants of this study are the eleventh graders of SMK Negeri 2 Salatiga. The eleventh graders (11 TEI B) consists of 35 students with male and female. The eleventh graders' students are chosen for the subject of this study. They are about seventeen years old. Since they were in elementary school, they have learned 
English, while listening and speaking skills are commonly taught. As appropriate with the specific social situation with such research questions, they have been chosen. They were also supposed to know best about what the researcher expects.

The research instrument is a tool or device to measure phenomena being observed. Arikunto (2010, p. 192) states that there are two types of instruments: test and non-test instruments. This test seems to be a compilation of queries or exams and other instruments. This research uses a test instrument (speaking test) and an interview. These tests are containing the vowels sound of English [ıə], [ชə], [er], [eə], and [əひ].

Speaking Test. This test refers to measure the ability of the students in pronouncing the sounds [гә], [৩ә], [er], [еә], and [әч]. This test is reading test sheets containing 50 words conducted by the researcher. The students were asked to read a list of words that is pronounced loudly and correctly. Several words are providing the English

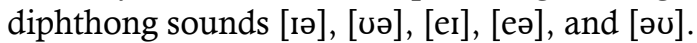

Interview Guide. According to Esterberg as cited in Sugiyono (201, p. 231), an interview is an exchange of information and opinions between two people through question and answer, which contribute to dialogue and a meaningful understanding of a particular topic. In this research, there were some basic questions concerning research problems in the interview. The questions concerned the background and the knowledge of the diphthong sounds and their difficulties in pronunciation. In this interview, the researcher received the information concerning the kinds of errors in pronouncing made by the participants.

Audio Recording. As the students pronounced those words, the researcher is recorded the students' pronunciation. In the pronunciation test, the instruments needed are a tape recorder and the list of words written in the pronunciation test sheet. As well as during the interview, the researcher is recorded the students' answers.

The researcher used a speaking test and interview to collect the data: Doing a Speaking Test. The participants pronounce some words that consist of the English diphthong sounds which Bahasa Indonesia does not have. There were 50 words that had to be read. The participants are asked to pronounce the words containing the English diphthong sounds by reading aloud the word individually, while their pronunciations are recorded. Doing Interviews. In this section, the researcher wants to investigate more English language learning background. Some questions related to pronunciation difficulties were answered by the students individually. The answers of the students were recorded as well.

To identify the collected data, the researcher identifies the data through descriptive analysis. The researcher followed some steps they are identifying, describing, explaining, the criterion of interpreting data, observing the interviews, reporting the interviews, and drawing the conclusion. Identifying the Types of Errors. In this step, the students' pronunciations were checked after the researcher transcribed the students' pronunciation into the phonetic transcription. Then, the researcher compares the students' transcription with the correct transcription in Oxford Learner Dictionary.

Describing and Explaining Errors. In the next steps, the researcher describes the students' errors after identified the students' errors. The researcher will classify the types of errors which occurred and also make a table of students' errors and count the percentage, which contains the total number of error produced by the students.

The Criterion of Interpreting Data. The researcher analyzed the result of this research using qualitative method. The researcher used criterion based on Tinambunan's criterion in Tartiasih as cited in Puspitasari (2016), which used to know how well the students produce English diphthong sounds whether poor, good, or excellent.

Table 1. Tinambunan's Criterion

\begin{tabular}{cc}
\hline Number of errors (\%) & Level of ability \\
\hline $0-25$ & Excellent \\
$26-50$ & Good \\
$51-75$ & Fair \\
$76-100$ & Poor \\
\hline
\end{tabular}

Observing the Interview Results. After conducting the error analysis steps, the researcher found the kinds of errors are mostly found in the students' pronunciation. The researcher interviewed the students who had to be recorded. The researcher played and listened attentively to the audio recordings of the interviews. Reporting the Interviews. When conducting the interviews, the researcher only took relevant information from the interviewees and reduced some irrelevant information from interviewees. Drawing the Conclusion. The researcher concludes the data after got the identifying data.

\section{RESULTS AND DISCUSSION}

Based on the research conducted in SMK $\mathrm{N} 2$ Salatiga, the data are gained from speaking tests and interviews. The speaking test is intended 
to determine the ability of students to produce English diphthong sounds that are not found in Bahasa Indonesia. Besides, interviews are used as additional data in this research.

In the speaking test, 50 words provided by the researcher were required to be pronounced by students. The researcher provided 10 words for each sound. From 35 students, there were 1750 utterances gained in the speaking test. To see the students test results, we can see from the Table 2.

Table 2. The Students' Test Result in Pronunciation Test

\begin{tabular}{lcc}
\hline English & \multicolumn{2}{c}{ Percentage of } \\
\cline { 2 - 3 } Diphthong & Error & Correct \\
\hline [ıә] & $68 \%$ & $32 \%$ \\
[๘ә] & $81 \%$ & $19 \%$ \\
[ег] & $40 \%$ & $60 \%$ \\
[еә] & $73 \%$ & $27 \%$ \\
[ә兀] & $79 \%$ & $21 \%$ \\
\hline
\end{tabular}

Based on the pronunciation test, it showed that the students find it more difficult in pronouncing the English diphthong sound [və], then followed by the sound [ə兀], [eə], and [Iə]. Whereas in pronouncing the diphthong sound [er], only a few students found it difficult to pronounce. Most of the students omitted the English diphthong sound by the pure vowel sounds. Some previous studies showed that the lack of certain sounds in the mother tongue of the students might cause them problems. As explained before that the English diphthong sounds [ı], [vә], [ег], [еә], and [ə兀] do not exist in Bahasa Indonesia. A foreign student uses a vowel too close to the first part that is the general error. For the pronunciation of the sound [və], based on the Tinambunan's criterion, in pronouncing sound [चə] the students' level was classified as poor. The findings showed in the word 'pure' and 'cure'; there were no students who pronounced it correctly. All of the students omitted the sound [Uว] by the pure vowel [U] and [ə]. The findings of this study were related to a study conducted by Nafsik (2018), who found that the students omitted the sound [Uə] by the pure vowel [v]. This study also related to research done by Sari, Fatmasari (2019) who found that the students find it difficult in pronouncing diphthong [ขə]. In line with Donal's study (2016), he stated that the different sound system between Indonesian and English made Indonesian students faced difficulties when pronouncing English words. Some students also substituted the sound [və] by the sound $[\varepsilon],[o],[u a]$, and [ou]. For example, in pronouncing the word 'curios', one of the students pronounced as [keriəs], [koriəs]. In the word ' $v i$ sual', there were seven students pronounced as [vizual], while in the word 'tour', three students pronounced as [tour].

Next, in pronunciation of the sound [Iə], [eə], and [əv], the students' score was better than what they did in the pronunciation of the sound [Uə]. The students' level in pronouncing sound [Іә], [еә], and [ә兀] were categorized as fair. The findings showed that many students omitted the English diphthong sounds [Iə], [eə], and [əu] with some pure vowel sounds. The general error made is that they start it too closely with a vowel position. For example, when the students pronounce the word 'era' as [Irə], [Ira], and [əra]. The student tended to pronounce the word 'career' as [karr r], [kərı r], [kerı r], and [kerə r]. There were only two students who pronounce the word 'career' correctly. Almost all of the students pronounced the word 'fear', 'real', 'tear', 'dear' and 'near' as [f r], [ril], [tr r], [di r], and [nı r]. The students also pronounce the word 'beard', 'here', 'mere' as [bid], [bəd, [hr r], [hə r], [mI r], and [mər]. This result is in line with Donal's study (2016) that a pure vowel sound replaced the most outstanding problem in pronouncing the diphthong [Iə]. Some students also substituted the sound [Iə] by the sound $[\varepsilon]$ because that sounds exist in Bahasa Indonesia. For example, in pronouncing the word 'era', there were eighteen students pronounced as [cra]. In the pronunciation of the sound [eə], some students omitted the English diphthong sound [eə] by the pure vowel sound $[\varepsilon]$ and [ə]. From the table above we know that not only omitted the sound [er] but the students also substituted the sounds by other sounds, such as [er], [Iə], and [ar] sounds. For example, the word 'pair', 'hair', and 'fair' that should be pronounced as [peə], [heə], and [feə] but many students pronounced as [peI $\mathrm{r}$ ], [pai r], [hei r], [hai $\mathrm{r}$, and [feI r], [fai r]. In pronouncing the words 'care', 'bare', 'where', 'rare', and 'wear', the students omitted the sound [eə] become pure vowel sound $[\varepsilon]$ and [ə]. The students pronounced as [ke r], [kə r], [be r], [bə r], [we r], [wə r], [re r], and [rə r]. While in pronouncing the words 'dare', and 'scary', almost all of the students pronounced as [de r] and [skerr], that's mean the students omitted the sound [eə] by the sound $[\varepsilon]$. In pronouncing some words containing English diphthong sound [əv], the students omitted the English diphthong sound [və] by the pure vowel sound [o]. For instance, the word 'focus', 'bold', 'hold', and 'road' that should be pronounced as [fəukəs], [bəuld], [həuld], [rəud], but the students pronounced as [fokəs], [fokus], [bold], [hold], 
[həld], [rəd], and [rud]. As well as the word 'snow', 'only', 'ocean', 'open', 'over' and 'home' that should be pronounced as [snəひ], [əunli], [əufn], [əupən], [əuvə], and [həum] but many students pronounced it as [sno], [onlr], [ofn], [opən], [ovə $\mathrm{r}]$, and [hom]. These findings were related to the study done by Nafsik (2018), who found that more than $40 \%$ of the participants did error in pronouncing English diphthong sound [ə兀]. Nafsik (2018) stated that the participants who did error in pronouncing English diphthong sound [əu] were because they were distracted by orthographic writing, or by vowels and diphthong sounds existing in their native language. Moedjito (2016) claimed that sometimes the students were confused by orthographic writing because the same spelling is not often pronounced in the same manner.

Furthermore, in pronunciation of the sound [er], the students did not make any error pronunciation. The students' level in pronouncing the word containing English diphthong sound [er] were categorized as good. In pronouncing the word 'may' and 'they', the students did not omit the sounds, but they have substituted the diphthong sound [eI] become pure vowel [ar]. There were seven students pronounced 'may' as [mar], and there were two students pronounced

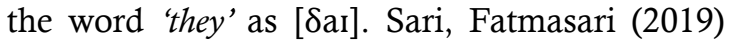
stated in their study that when the speaker makes mistakes which are saying the word with the wrong phonetic transcription, it is called as cultural sound adjustification. In the word 'late', 'wait', 'pain', 'race', 'take, 'hate', 'game', some of the students omitted the sound [er] by the sound $[\varepsilon]$, as many of the students pronounced as [let], [wet], [res], [tek], [het], and [gem]. While the lowest percentage was the error of pronouncing the word "wait" with the percentage of errors at $11.42 \%$. There were only two students omitted the English diphthong sound [er] with pure vowel sound $[\varepsilon]$. In the word 'great', there were seventeen students pronounced as [grit] and two students pronounced as [gret].

Followed by the explanation provided above, we know that many students made errors in pronouncing the words containing English diphthong sound [гə], [vә], [er], [eə], and $[\partial \mho]$. It was written in Ramelan's book (2003, p.4) that a foreign language student would be difficult to pronounce like native because it is out of his habit speech sounds. However, for many Indonesian students, a whole new sound system is hard to hear or duplicate. These difficulties caused by the difference between the sound system in Indonesian and English. Ramelan (2003) also claimed that when the native language has different elements on sounds with the students' target language, it is directly related to the difficulties students have in studying English as a second language. Also, Lanteigne (2006), as cited in Donal's study (2016), confirms some of the English sounds that not present in the learners' mother tongue caused the difficulties in learning English. Indonesian students should attempt to produce sufficient diphthong in English, as they tend to replace that by a pure vowel in Indonesia we know that the diphthongs sounds are mostly omitted and replaced by the pure vowel sounds. As explained in the first chapter that this research not only to describe how well the students pronounce the English diphthong sounds which do not exist in Indonesian but also to find out the kind of errors are mostly found in students' pronunciation of English diphthong sounds which do not exist in Indonesian. Therefore, to find the kind of errors, the researcher using the interview as additional data.

In this interview, the questions were related to the students' English background, students' knowledge of the diphthong sounds, and difficulty of students to pronounce English diphthong sounds. The researcher recorded the interviews. Then, the responses of the interview were analyzed by the researcher. There were ten questions given to the participants. The first question was about the students' come from. From the table above, we know that all of the students come from Java, there is 34 students, or $97.13 \%$ of the total students who come from Central Java, there only one student who comes from Bogor, West Java. The second question about students' parent's English native language, there only one student or $2.85 \%$ of the student whose parents are English native speakers. Next, the third question is about what language they usually use in their daily life. There were twenty students or $57.14 \%$ of students answered that their native language is Javanese, four students or $11.42 \%$ of students answered that their native language is Indonesian. Another eleven students or $31.42 \%$ of students use Indonesian and Javanese language.

Then, the researcher asked questions about students' knowledge of the diphthong sounds. The fourth question was about diphthong sound recognition in students' native language. There were $34.28 \%$ of the students' answered that there were any diphthong sounds in their native language. The fifth question was regarding their knowledge about the English diphthong sounds. There were $71.42 \%$ of the total of the students have known about English diphthong sounds. 
Table 3. Students' Responses to the Interview

\begin{tabular}{lll}
\hline Questions & Response & Percentage \\
\hline Student origin & Salatiga & $71.42 \%$ \\
& Semarang & $25.71 \%$ \\
Parents as an English native speaker & Bogor & $2.85 \%$ \\
& Yes & $2.85 \%$ \\
Student native language & No & $97.14 \%$ \\
& Javanese & $57.14 \%$ \\
Diphthong sound recognition in student native language & Indonesian & $11.42 \%$ \\
& Javanese and Indonesian & $31.42 \%$ \\
& Yes & $34.28 \%$ \\
English diphthong sounds recognition & No & $45.71 \%$ \\
& Don't know & $20 \%$ \\
English diphthong sounds recognition in student native & Yes & $71.42 \%$ \\
language & No & $28.57 \%$ \\
Have studied diphthong sound in student native language & Yes & $40 \%$ \\
& No & $60 \%$ \\
Have studied how to pronounce diphthong sound [eə] & Yes & $28.57 \%$ \\
in student native language & No & $71.42 \%$ \\
The difficulties in pronouncing diphthong sound [eə] & Yes & $45.71 \%$ \\
& No & $54.28 \%$ \\
& Rarely & $80 \%$ \\
Students' opinion about the difficulties in pronouncing & Unfamiliar & $17.14 \%$ \\
diphthong sound [eə] & Similar & $2.85 \%$ \\
& Don't know & $68.57 \%$ \\
& Different spelling & $11.42 \%$ \\
& Javanese mother tongue & $8.57 \%$ \\
& & $17.14 \%$ \\
& & $5.71 \%$ \\
\hline
\end{tabular}

Then, the researcher asked the students' knowledge about diphthong sound [гə], [نə], [er], [eə], and $[\partial v]$ in their native language. $60 \%$ of students stated that they have not known about diphthong sound [rə], [نə], [er], [eә], and [əu] in their native language. The researcher also asked whether or not they learned diphthong sound [eə] in their native language, $54.28 \%$ of the students answered that they didn't learn diphthong [eə] in their native language.

The next question was about their experience in being taught about how to pronounce diphthong sounds in their native language. There were $54.28 \%$ of the students answered that they have not been taught about how to pronounce diphthong sound [eə] in their native language. Then, the researcher asked the student's perception of whether or not they feel difficult in pronouncing diphthong sound [eə]. Almost all of the students stated that they feel difficult when pronouncing diphthong sounds. The researcher also asked the students' opinions about why they find it difficult when pronouncing diphthong sounds.
There were $68.57 \%$ of the students answered that the unfamiliarity of diphthong sounds caused the difficulties, $17.14 \%$ of the students answered that English words have different spelling with Indonesian, $11.42 \%$ of the students answered that the diphthong sounds have similar each other to pronounce, $8.57 \%$ of the students answered diphthong sounds as they don't know, and $5.71 \%$ of the students answered because of the differences in the mother tongue.

Another purpose of this research is to decide what kind of errors are mostly found in students' pronunciation. The researcher interviewed as additional data to answer that statement's problems in which responses were had been described before. From the students' responses, the researcher concluded that many Indonesian students still lack knowledge about English diphthong sounds. Most of them didn't know about English diphthong sounds. It was because the English language is not their mother tongue. Besides, the English diphthong sound [гə], [৩ә], [er], [eə], and [ə๘] do not exist in their native lan- 
guage. Some of them said that they never been taught how to pronounce that sounds, that is why many of them felt difficult when pronouncing that sounds.

It was explained before there are three types of errors, substitution, omission, and insertion. Based on the findings, there were a lot of the students omitted the English diphthong sounds by the pure vowel sounds. The total number of the students' transcripts in utterance was 1.750 , and there were only 549 words pronounced by the students following the transcript. There were 1007 of the total transcripts were the students made omission errors. While there were 194 of the total transcripts of the students made substitution errors. It means that the kind of errors that are mostly found in this research is omission errors. Several aspects are supposed to influence the errors of pronouncing English diphthong sounds. According to Ramelan (1999:4-5), that habit of someone to pronounce a word that involves diphthong is among the factors that affected error pronunciation. From the students' responses in interviews, almost all of the students' native language is Javanese. It showed that their language habits are not English. In addition, Donal (2016) also confirmed that their native language had a great influence on the way of the students spoke English sound. The students stated that they feel difficult to pronouncing English diphthong sounds because the differences between English and Javanese were significant. So, it caused the students to omit the English diphthong sounds with the pure vowel sounds which exist in their native language.

\section{CONCLUSION}

Depending on the results of the previous chapter, certain conclusions can be reached. The first objective conducted was investigating how well English diphthong sounds are pronounced by the eleventh-grade students of TEI B SMK N 2 Salatiga. It can be seen in the previous chapter that the students are considered "Fair" in the pronunciation of English diphthong sounds. The total average in incorrect numbers of English diphthong sounds pronunciation made by students was $69 \%$ of the total pronunciation 1750 . Some students made errors in pronunciation. The students' errors in pronouncing English sound [və] got the highest percentage that was $81 \%$. It was categorized as poor. Then, the percentage of errors in pronouncing diphthong sound of English that were categorized as the fair was the sound [Iə], [eə], and [ə兀] with each percentage was $68 \%, 73 \%$, and $79 \%$. Besides, the lowest percentage of the error of the students when they pronounce English diphthong sounds were categorized as good with the error percentage was $40 \%$, which is in the sound [er].

Then, the next objective conducted was investigating what kind of errors are mostly found in the pronunciation of English diphthong sounds of the students. Based on the findings above, there were a lot of the students omitted the English diphthong sounds by the pure vowel sounds. The total number of the students' transcripts in utterance was 1.750 , and there were only 549 words pronounced by the students following the transcript. There were 1007 of the total transcripts were the students made omission errors. While there were 194 of the total transcripts of the students made substitution errors. It means that the kind of errors that are mostly found in this research was omission errors.

\section{REFERENCES}

Ahmed, Z. A. D. (2017). Difficulties encountered by EFL students in learning pronunciation: A case study of Sudanese higher secondary schools. International Journal of English Linguistics, 7 (4), 75-82.

Al Zayed, N. N. (2017). Non-Native Pronunciation of English: Problems and Solutions. American International Journal of Contemporary Research, $7(3), 86-90$.

Arikunto, S. (2010). Prosedur Penelitian: Suatu Pendekatan Praktik. PT Asdi Mahasatya.

Brown, H. D. (2000). Principles of Language Learning and Teaching, Fourth Edition. Longman.Inc

Crystal, D. (2003). English as a global language $2^{\text {nd }} e d$. Cambridge University Press.

Donal, A. (2016). Indonesian Students' Difficulties in Pronouncing English Diphthongs. International Journal of English Education, 2(2), 55-62.

Ellis, R. (1997). Second language acquisition. Oxford University Press.

Gilakjani, A. P. (2011). Why is Pronunciation so Difficult to Learn? International Journal of English Language Teaching, 4(3), 74-83.

Jing, H., Xiaodong, H., \& Yu, L. (2016). Error Correction in Oral Classroom English Teaching. English Language Teaching. 9(12), 98-103.

Jones, D. (1956). The Pronunciation of English. Cambridge University Press.

Khan, A., Shehzad, W., \& Ullah, I. (2017). Articulation of English Consonants, Vowels, and Diphthongs by Pashto Speakers in Khyber Pakhtunkhwa, Pakistan. International Journal of English Linguistics, 7(5), 19-33.

Kosasih, M.M. (2017). Native Language Interference in Learning English Pronunciation: A Case Study at A Private University in West Java, In- 
donesia. International Journal of Education and Research, 5(2), 135-150.

Moedjito. (2016). The teaching of English pronunciation: Perceptions of Indonesian school teachers and university students. English Language Teaching, 9(6), 30-41.

Nafsik, A. K. (2018). An Error Identifying in Perception and Production English Diphthongs Pronounced by Non-English Department Students. Final Project of English Department Students FBS UNNES.

Nassaji, H. (2015). Qualitative and descriptive research: Data type versus data analysis. Lan guage Teaching Research. 19(2), 129-132.

Puspitasari, R. I. (2016). Students' Error in Perception or Production of Pronouncing Short and Long English Vowels (A Case Study of the Eighth Grade Stu- dents of SMP N 2 Demak in the Academic Year 2015/2016). The research report, English Department, Faculty of Languages and Arts, Universitas Negeri Semarang.

Ramelan. 1977. English Phonetics. IKIP Semarang Press.

Roach, P. (2000). English Phonetic and Phonology: A Practical Course (3rd ed.). University Press, p. 2

Sari, K. M., \& Fatmasari, Y. (2019). Errors analysis on English diphthongs pronounced by Indonesian students in English debate competition posted on Youtube. Dialektika Journal PBI, 7(1), 38-55.

Syafei, A. (1988). English Pronunciation: Theory and Practice. Ministry of Education and Culture.

Sugiyono. (2013). Metode penelitian kuantitatif, kualitatif dan $R \& D$. Alfabeta. 